\title{
JOURNAL.RU
}

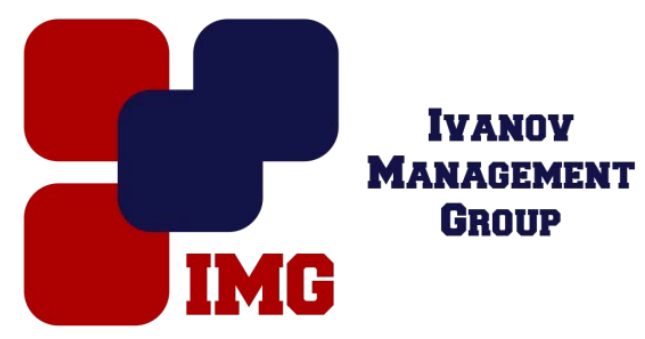

Мусатаева М.Ш., Есиркеева Д.А. Казахский наииональный педагогический университет имени Абая Алматы, Республика Казахстан

doi: 10.18411/lj-31-10-2016-3-08

idsp 000001:lj-31-10-2016-3-08

\section{О некоторых вопросах современной лингвоконцептологии}

\section{Аннотация.}

В данной статье делается попытка представить тенденции в развитии лингвоконцептологии на сегодняшний день и перспективы исследований в данном направлении в российской и казахстанской когнитивной лингвистике.

Ключевые слова: когнитивная лингвистика, концептология, вербализация, ментальная картина мира, язык, культура, менталитет.

\section{MussatayevaM.Sh.,Yesirkeyeva D.A.}

Kazakh National Pedagogically University named after Abai.

\section{On some issues of contemporary lingvokontseptologii}

\section{Abstract}

This article attempts to provide trends in lingvokontseptologi to date and the prospects for research in this area in the Russian and Kazakh cognitive linguistics.

Keywords: cognitive linguistics, conceptology, verbalization, the mental picture of the world, language, culture, mentality.

Когнитивная парадигма, дающая возможность осмысления ментальной картины мира языкового субъекта через концепты, во многом определяет развитие современной науки о языке и перспективы языкознания в будущем. Этой проблеме в русистике посвящена богатая литература (см. работы Н.Д. Арутюновой, Н.С. Болотновой, А. Вежбицкой, М.Я Дымарского, Ю.Н. Караулова, Е.С. Кубряковой, Н.А. Николиной, З.Д. Поповой, И.А. Стернина, 
Ю.С. Степанова, Р.М. Фрумкиной, А.Д. Шмелева, Г.И. Берестнева, Г.В. Звездовой и др.).

Признавая первенство американской когнитивной лингвистики, относительно, замечания Т.Г.Скребцовой о том, что российские ученые «повидимому, в силу недостаточной осведомленности зачастую искаженно представляют суть данного направления, неправомерно расширяя или, наоборот, сужая его объем, выдавая периферийные явления за центральные и т.д.» [2, с. 4]хотелось бы отметить закономерность данной ситуации в условиях формирования нового научного направления. Проведем небольшую параллель. Некогда прикладная лингвистика в представлении американских ученых зачастую связывалась с методикой преподавания иностранных языков, а в советской лингвистике - c компьютерной лингвистикой. Однако это обстоятельство не помешало бурному развитию данной отрасли, не только совместившей в себе две национальные традиции, но значительно расширившей свое содержание за счет новых направлений (квантитативная лингвистика, корпусная лингвистика, практическая лексикография, перевод, автоматическая обработка текста и др.), в том числе компьютерной лингвистики и лингводидактики.

На сегодняшний день в когнитивной лингвистике наиболее ярко выделяются две исследовательских традиций: американская и российская. Свидетельством поиска совместных путей решения дискуссионных вопросов данной молодой отрасли языкознания являются научные издания и форумы (симпозиумы, конгрессы, Международные конференции и др.). В качестве примера приведем научный сборник «Методологические проблемы когнитивной лингвистики» (Воронеж, 2001) изданный при поддержке российских (Воронежский Межрегиональный институт общественных наук, Воронежский государственный университет, Московский общественный научный фонд) и американских (Институт перспективных российских исследований имени Кеннана, США при поддержке Корпорации Карнеги в Нью-Йорке и Фонда Джона Д. и Кэтрин Т. МакАртуров, США) научных центров. Данный сборник посвящен таким актуальным проблемам лингвокогнитологии, как: методология когнитивных исследований, методика лингвистического описания содержания концептов, методика исследования процессов концептуализации и 
категоризации, методика исследования возрастных концептов, исследования концептов на материале художественного текста. Оговорка в тексте аннотации сборника о том, что «точка зрения, отраженная в данном издании, может не совпадать с точкой зрения доноров и организаторов программы» еще раз подтверждает сложность и неодназначность многих проблем.

Языковая объективация концептуальной картины мира осуществляется через лингвокогнитивное описание ее фрагментов.Изучение концептов вызывает большой исследовательский интерес, причем некоторые концепты становятся объектом изучения исследователей различных направлений. Каждое последующее исследование раскрывает новые грани исследуемого концепта, что многократно подтверждает многомерность, глубину и сложность данного феномена и невозможность в полном объеме раскрыть его содержание.

В современной русистике самой активно исследуемой областью является лингвистическаяконцептология, занимающаяся описанием наименований концептов языковыми средствами. Свидетельство тому - наличие в русистике целого ряда лингвоконцептологических школ: когнитивно-семасиологической лингвокультурологии, сформировавшаяся в стенах Волгоградского государственного педагогического университета (Н.Ф. Алефиренко, И.И. Кайгородова, Е.В. Сенько, Г.В. Токарев, Л.А. Шестак, и др.); психолингвистики (в Барнауле - Е.В. Лукашевич, В.А. Пищальникова и др., в Твери - А.А. Залевская и др.); научной теоретико-лингвистической щколы Воронежского университета (А.П. Бабушкин, З.Д. Попова, О.Н. Ракитина, И.А. Стернин и др.), новомосковской школы концептуального анализа (Анна А. Зализняк, И.Б.Левонтина и др.) и др.

Представители лингвоконцептологических школ расходятся в определении методов и приемов анализа концепта, но единодушны в определении концепта как основной единицы сознания, вербализующейся языковыми средствами.

На постсоветском пространстве «пальма первенства» в когнитивной лингвистике принадлежит российским исследователям. Несмотря на сравнительную «молодость» казахстанской когнитивной лингвистики ею накоплен определенный опыт. Работы казахстанских лингвокогнитологов в своем большинстве посвящены лингвокогнитивному анализу доминантных 
концептов казахской национальной концептосферы и лингвокогнитивному сопоставительному анализу концептов преимущественно казахской и русской концептосфер, а также для сопоставительного анализа привлекаются концептосферы носителей других языков и культур. В этой связи следует исследования, проводимые в научной лаборатории известного казахстанского ученого З.К.Ахметжановой «Казахская концептология».За исходную точку анализа концептов принята «семантическая трапеция»: «язык - мышление действительность - культура», что органично согласуется с идеей концепта, синтезировавшем означаемое (культурные знания), означающее (языковой знак) и обозначаемое (денотат). При этом акцентируется внимание на репрезентантах каждой составляющей ряда: реалиях как фрагментах казахской культуры; концептах как моделях представления знаний - выразителях национальной ментальности; лексемах, вербализующих культурные знания как историческую память народа.

На современном этапе ведутся активные лингвокогнитивные исследования, посвященные следующим проблемам: категоризации, концептуализации и когнитивному моделированию; аксиологической картине мира в языке; диалектным концептам; вербализации концепта, взаимодействие систем мышления и языка; теоретической и когнитивной семантике, взаимосвязи и взаимообусловленности ЯКМ и системной лексикографии; когнитивной метафоре; когнитивному изучению текстов; когнитивнодискурсивной парадигме; когнитивному анализу предметных имен и глаголов; когнитивным исследованиям на материале Национального корпуса русского языка; концептуальным основам семантических инноваций; когнитивному моделированию в лексике и фразеологии, невербальной семиотике; когнитивной лексикографии, когнитивному словообразованию (М.А.Кронгауз), речевой деятельности как манипулированию внутренними когнитивными структурами сознания (когнитивными моделями, ментальными репрезентациями и т.п.), лингвоконцептологические исследования на материале художественных произведений.

Таким образом, несмотря на активные исследования вышеперечисленных проблем, они нуждаются в дальнейшем углубленном исследовании. Приведем ряд актуальных проблем, решение которых будет способствовать решению не 
только лингвокогнитологии, но и других когнитивных наук: необходимость более четкого разграничения между ментальными и языковыми репрезентациями; анализ институциональных дискурсов с когнитивных позиций; изучение когнитивных факторов, обусловленных взаимодействием языка и культуры; разработка общей методологии и новых методов анализа семантики слова с учетом достижений различных национальных лингвокогнитивных традиций (американской, западной, российской, казахстанской и др.) анализа.

\section{Литература}

1. Ахметжанова 3.К., Мусатаева М.Ш. Актуальные проблемы лингвокогнитологии и лингвокультурологии. - Алматы: 2013. - 232 с.

2. Скребцова Т.Г. Когнитивная лингвистика, Курс лекций. - СПб, 2011. C.254. 